\title{
Immunomodulation and Safety of Topical Calcineurin Inhibitors for the Treatment of Atopic Dermatitis
}

\author{
Thomas Hultsch $^{\mathrm{a}}$ Alexander Kapp ${ }^{\mathrm{b}}$ Jonathan Spergel ${ }^{\mathrm{c}}$ \\ ${ }^{a}$ Novartis Pharmaceuticals Corporation, East Hanover, N.J., USA; ${ }^{b}$ Department of Dermatology and \\ Allergology, Hannover Medical University, Hannover, Germany; ${ }^{c}$ Division of Allergy and Immunology, \\ The Children's Hospital of Philadelphia, Philadelphia, Pa., USA
}

\section{Key Words}

Calcineurin inhibitors · Atopic dermatitis ·

Topical corticosteroids $\cdot$ Immunosuppression .

Lymphoproliferative disease $\cdot$ Th1/Th2 balance

\begin{abstract}
Atopic dermatitis $(A D)$ is a chronic or chronically relapsing inflammatory skin condition that primarily affects children. Topical corticosteroids have been the mainstay of treatment since the late 1950s. While providing excellent short-term efficacy, topical corticosteroid usage is limited by potential adverse effects, including impairment of the function and viability of Langerhans cells/ dendritic cells. The recently introduced topical calcineurin inhibitors pimecrolimus cream $1 \%$ (Elidel $^{\circledR}$ ) and tacrolimus ointment 0.03 and $0.1 \%$ (Protopic ${ }^{\circledR}$ ) exhibit a more selective mechanism of action and do not affect Langerhans cells/dendritic cells. For the immune system of young children 'learning' to mount a balanced Th1/ Th2 response, this selective effect has particular benefits. In clinical experience, topical calcineurin inhibitors have been shown to be a safe and effective alternative to topical corticosteroids in almost 7 million patients $(>5$ million on pimecrolimus; $>1.7$ million on tacrolimus). Topical pimecrolimus is primarily used in children with
\end{abstract}

mild and moderate $A D$, whereas tacrolimus is used preferentially in more severe cases. None of the topical calcineurin inhibitors have been associated with systemic immunosuppression-related malignancies known to occur following long-term sustained systemic immunosuppression with oral immunosuppressants (e.g., tacrolimus, cyclosporine A, and corticosteroids) in transplant patients. Preclinical and clinical data suggest a greater skin selectivity and larger safety margin for topical pimecrolimus.

Copyright (C) 2005 S. Karger AG, Basel

\section{Introduction}

Atopic dermatitis (AD) is one of the most common childhood skin diseases, affecting up to $25 \%$ of the population in the United States, Europe, and Japan. The onset of $\mathrm{AD}$ is in the first year of life in $60 \%$ of affected individuals, and before the age of 5 in at least $85 \%[1,2]$. Similar to other atopic diseases (e.g., asthma and allergic rhinitis), there has been a dramatic 2- to 3-fold increase in the incidence of $\mathrm{AD}$ over the last 30 years in industrialized countries. However, in countries with principally rural or agricultural areas, the prevalence has remained much lower [3]. Recent studies have shown clearing of

\section{KARGER}

Fax +4161306 1234 E-Mail karger@karger.ch www.karger.com
(C) $2005 \mathrm{~S}$. Karger AG, Basel

$1018-8665 / 05 / 2112-0174 \$ 22.00 / 0$

Accessible online at: www.karger.com/drm
Thomas Hultsch

Novartis Pharmaceuticals Corporation East Hanover, NJ 07936-1080 (USA)

Tel. +1 862778 3550, Fax +1 9737814214

E-Mail thomas.hultsch@novartis.com 
$\mathrm{AD}$ around puberty in approximately 50\% of affected patients $[4,5]$. Therefore, the lifetime prevalence of $\mathrm{AD}$ in children is $10-20 \%$, and the lifetime prevalence in adults is $1-3 \%$ in industrialized countries [3]. AD also has dramatic effects on patient quality of life, leading to distress, anxiety, sleep disturbance, poor self-esteem and low self-confidence. In fact, $60 \%$ of the daily activities of school-age children are adversely affected [6-9].

\section{Atopic Disease and Dysregulation of the Immune System}

Although the cause of AD is not well understood, it is often associated with the development of other allergic diseases such as asthma and allergic rhinitis [2]. In a prospective birth cohort study in infants with an atopic family history and $\mathrm{AD}$ at the age of 3 months, the risk of developing asthma at age 5 was shown to be over 50\% [10]. In another study by Castro-Rodriguez et al. [11] in children with $\mathrm{AD}$ and parental asthma, $75 \%$ of the children developed asthma at school age. Severity of AD seems to have a major effect on the risk of developing respiratory allergies, and more than doubles the chances of asthma or allergic rhinitis as opposed to children with mild $\mathrm{AD}$ $[2,12]$. These studies indicate that the course toward an allergic career is determined early in life.

$\mathrm{AD}$ appears to be caused by a complex interaction of genetic and environmental factors that result in the dysregulation of the immune system $[3,13]$. The pattern of immune dysregulation is different at early stages of an atopic skin inflammation compared with a chronic AD lesion [14, 15], with a dominant Th2 pattern (IL-4, IL-5, IL-13) in acute $\mathrm{AD}$, as seen in young infants. Interestingly, the Th2-dominant immune response seen in early $\mathrm{AD}$ lesions or in young children with $\mathrm{AD}$ is qualitatively similar to the pattern observed in the immune response in young, non-atopic children: Th2 dominance, impairment of Th1. It could be speculated that this is one of the factors making young infants particularly susceptible to AD.

\section{Th2/Th1 Imbalance in Newborns and Young Infants}

In newborns and young infants, $T$ cell function is characterized by a poorly sustained Th 1 (IFN- $\gamma$ ) response and a propensity toward Th2 (IL-4, IL-13) production [16]. IFN- $\gamma$ production in response to polyclonal stimuli is diminished at birth, but increases thereafter through 3 years of age, when it approximates adult levels [17]. The impaired Th1 may be related to a lower secretion by anti- gen-presenting dendritic cells (APCs) of the Th1 polarizing cytokine IL-12 in response to Toll-like receptor ligands. Although neonatal T cells are somewhat limited in their ability to produce the Th2 cytokine IL-4, the production of IL-4 starts to rise rapidly at 4 months of age and peaks at higher-than-adult levels late in infancy before eventually declining to adult levels [16]. This results in a Th2/Th1 imbalance with predominance of Th2 over Th1 responses in older infants and children.

Dendritic cells (DCs) are the most potent APCs. Relatively early in gestation, DCs begin seeding peripheral tissues, and DC networks are readily recognizable in various tissues of the neonate. However, the density of DCs in these networks is lower than in adult tissue, and these DCs express lower levels of major histocompatibility complex (MHC) class II molecules, suggesting a decreased ability to elicit $\mathrm{T}$ cell activation. In many tissues, but particularly in the lung, DCs develop slowly with age and are impaired in neonates in their ability to respond to activation stimuli by increasing surface expression of MHC class II molecules and co-stimulatory molecules [18-20]. Langerhans cells (LCs) are DCs found in non-lesional and lesional skin and play a key role in the activation of $\mathrm{T}$ cells promoting the switch from naïve to effector cells in the lymph nodes. In contrast, inflammatory DCs have been reported to be highly expressed in lesional skin, but not in non-lesional skin $[15,21]$.

While the inability of the neonatal immune system to mount a strong cell-mediated immune response (Th1) may not result in clinical pathology in most cases, any external factors further impairing the maturation of a Th1 response may aggravate the innate defect to a level of a manifest clinical disease. Given the important role of APCs (especially LCs/DCs in the skin and lymph nodes) in enabling and maintaining a balanced Th2/Th1 response, a decreased function of this cell type would adversely affect the maturation of the immune response (fig. 1).

\section{Topical Treatments for AD}

In 1953, Sulzberger et al. [22] introduced the first topical corticosteroid (hydrocortisone) into clinical practice, providing a breakthrough in the treatment of atopic eczema. Since then, modifications of the basic molecular structure of hydrocortisone have led to the development of more potent topical steroids with the benefit of increased efficacy but the disadvantage of increased potential side effects. These side effects include skin atrophy, 


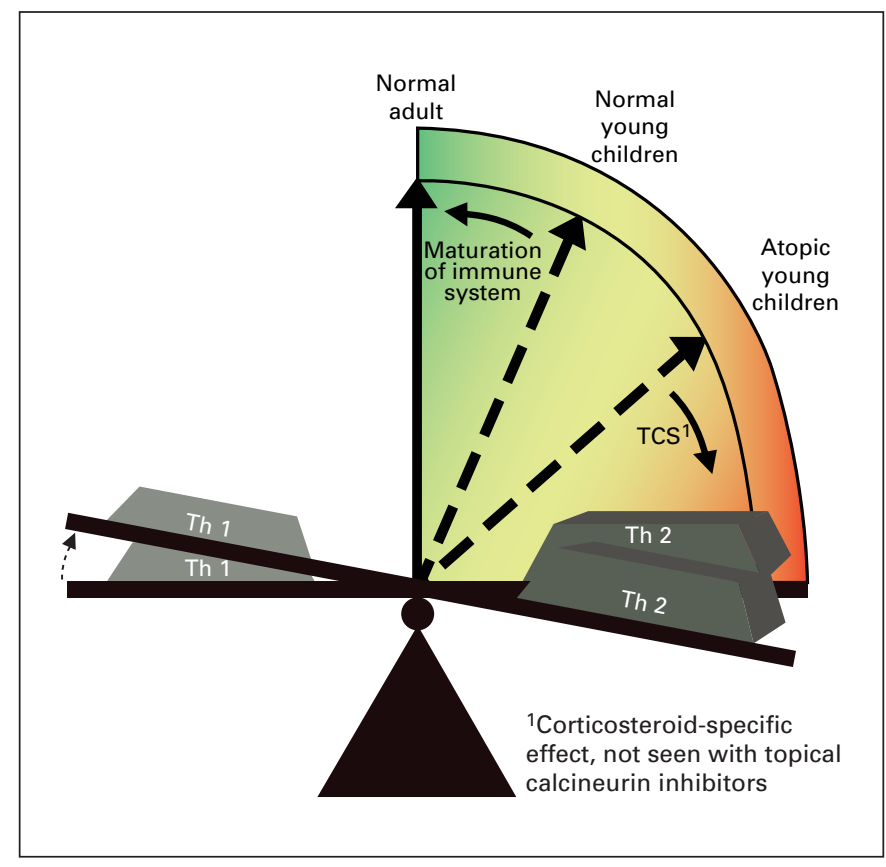

Fig. 1. The neonatal immune response in non-atopics is characterized by an impaired Th1 response and a propensity toward a Th2 response. In young children with $\mathrm{AD}$, the Th2/Th1 imbalance is exaggerated. Therapeutic interventions that impair the LC/DC function may adversely affect the natural maturation of the immune response.

striae, telangiectasia, acneiform eruptions, and the risk of absorption, leading to systemic effects such as hypothalamic-pituitary-adrenal (HPA) axis suppression. The mechanism of action of topical corticosteroids involves binding to an intracellular receptor, which forms a complex that interacts with DNA and affects transcription of a number of genes in a wide variety of cells [23]. On a molecular level, corticosteroids block the synthesis of inflammatory cytokines by affecting the nuclear factor kappa B pathway. On a cellular level, corticosteroids, even applied topically, affect the function and viability of LCs. Topical short-term treatment of even low potency corticosteroids eliminates LCs in the skin by inducing apoptosis. Experimental data show that after stopping application of topical corticosteroids, repopulation of the epidermis with LCs takes weeks [24-27].

Tacrolimus ointment, available in the United States since 2001, has been developed as a topical formulation of a systemic immunosuppressant used widely in transplantation (Prograf ${ }^{\circledR}$, Fujisawa Healthcare, Inc., Deerfield, Ill., USA). There is ample documented experience with the oral formulation of tacrolimus demonstrating its effectiveness as a systemic immunosuppressant and its risk associated with systemic immunosuppression, namely, the risk of immunosuppression-related lymphoproliferative diseases [e.g., Epstein-Barr virus (EBV), positive B cell lymphomas] [28, 29]. Topically applied tacrolimus ointment at concentrations of 0.03 or $0.1 \%$ has been shown to be effective in the treatment of $\mathrm{AD}$ and is approved for the treatment of moderate to severe AD [30-34].

Pimecrolimus cream $1 \%$ was the first calcineurin inhibitor developed specifically for the treatment of $\mathrm{AD}$, it was launched in the United States in 2002 with an approval for the treatment of mild to moderate AD. Shortand long-term trials including pediatric and adult patients with $\mathrm{AD}$ have demonstrated the effectiveness of pimecrolimus [35-44].

On a molecular level, both tacrolimus and pimecrolimus selectively inhibit the activation of $\mathrm{T}$ cells by inhibiting calcineurin, an enzyme required for dephosphorylation of the inactive cytosolic form of the $\mathrm{T}$ cell transcriptional regulatory factor known as nuclear factor of activated $\mathrm{T}$ cells $[45,46]$. The inactive form of nuclear factor of activated $T$ cells cannot enter the nucleus, so the production and release of inflammatory cytokines as well as $\mathrm{T}$ cell proliferation is inhibited. This was demonstrated in a study using $\mathrm{T}$ cell clones isolated from the skin of AD patients [45]. Pimecrolimus potently inhibited the proliferation of antigen-specific stimulated $\mathrm{T}$ cells and inhibited the production and release of inflammatory cytokines characteristic of both Th1 and Th2 cells [45, 47]. Furthermore, it was shown that pimecrolimus inhibits the expression of the cell surface co-receptor CD134. CD134 expression is increased in activated $\mathrm{T}$ cells and acts by inhibiting apoptosis of these cells. By suppressing CD134, pimecrolimus inhibits the survival of antigenactivated T cells $[45,47]$.

On a cellular level, recent studies demonstrated that while both pimecrolimus and corticosteroids inhibit $\mathrm{T}$ cell activation $[25,48]$, only pimecrolimus is selective, as it does not suppress viability and function of LCs in animals (fig. 2) [26, 49] and in humans (fig. 3) [25]. More specifically, in an in vitro study of mononuclear cells obtained from healthy volunteers, corticosteroids have been shown to cause apoptosis of monocyte-derived DC (M-DC) precursors and inhibit the expression of DC-specific antigens such as CD1a, CD40, and CD80. In addition, corticosteroids inhibit the expression of critical DC factors such as CD83 and CD86, the synthesis of IL12 p70, and the ability of DCs to activate primary CD4+ T cell proliferation [24]. Topical corticosteroids also have an adverse effect on IL-12 expression in LCs/DCs. IL-12 
Fig. 2. Effect of pimecrolimus and corticosteroids on LC density in murine epidermis. After twice-daily application for 5 days of pimecrolimus or corticosteroids, LC density was assessed. In contrast to pimecrolimus, topical corticosteroids significantly reduced LC density in murine epidermis. Reproduced with permission from Meingassner et al. [49].

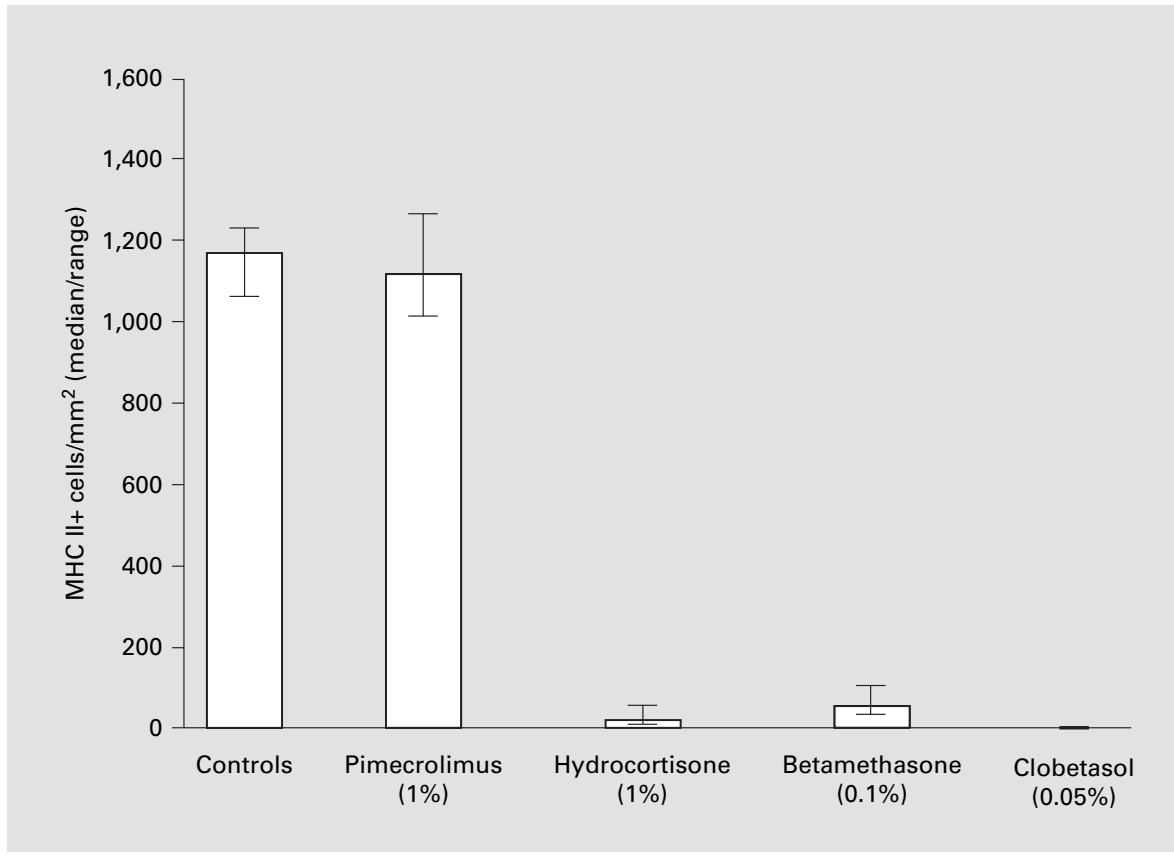

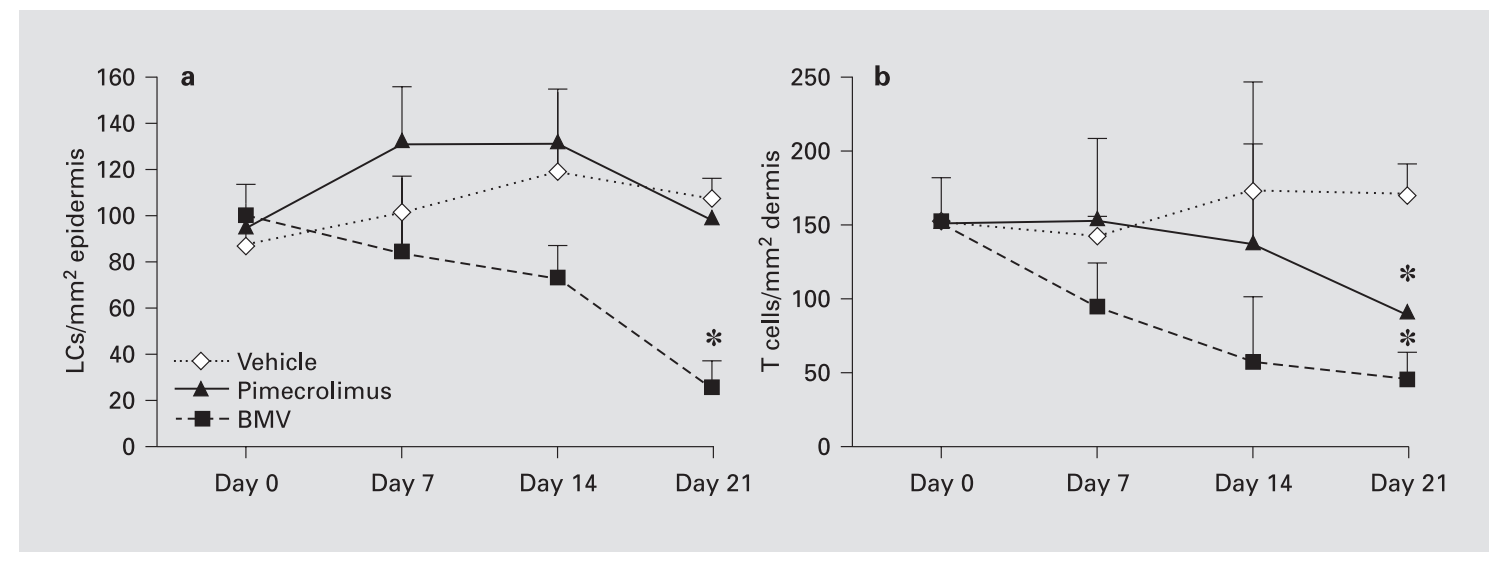

Fig. 3. Effect of pimecrolimus and corticosteroids on $L C$ and $T$ cell densities in human skin with AD. a Betamethasone valerate (BMV) cream, a mid potent topical corticosteroid, significantly reduced the number of LCs, whereas pimecrolimus, a topical calcineurin inhibitor, had no effect, being comparable to control. b In contrast, $\mathrm{BMV}$ and pimecrolimus both reduced the number of T cells. ${ }^{*} \mathrm{p}<0.01$ vs. control. Reproduced with permission from Hoetzenecker et al. [25].

is a major Th1-promoting cytokine and, therefore, a lack of IL-12 may further delay the maturation of the newborn's immune system [50]. It should be noted, that, while tacrolimus was not tested in most of the experiments above, it is likely that the effects observed are characteristic of the topical calcineurin inhibitor class. The effect of corticosteroids on DCs seems to be more pro- nounced in young children than in adults, as suggested in a study by Mainali et al. [51]. A comparison of the effect of dexamethasone on M-DCs obtained from cord blood with M-DCs obtained from adult blood demonstrated that dexamethasone sustains and enhances endocytotic activity, increases the expression of Th2 cytokines, and reduces Th1-promoting IL-12 in cord blood M-DCs, but 


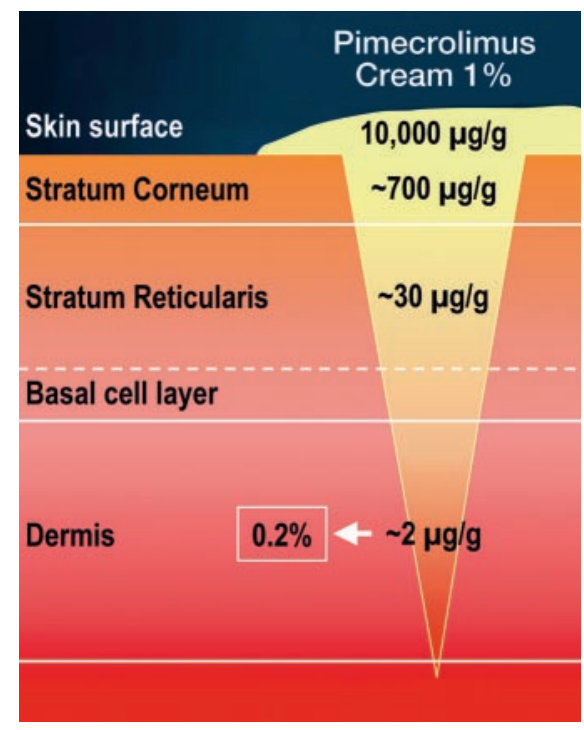

Fig. 4. Permeation (penetration) of pimecrolimus cream $1 \%$. When topically applied, only small amounts of pimecrolimus reach the dermis [60]. Data obtained from minipig skin studies using radioactive labeled pimecrolimus.

has only marginal effects on adult blood M-DCs. Taken together, the results demonstrate that topical calcineurin inhibitors act more selectively on the skin immune system and do not induce apoptosis in LCs/DCs. Therefore, these agents provide an interesting innovation in the treatment of $\mathrm{AD}$ and raise questions about the use of corticosteroids in young children with a developing immune system (fig. 1).

\section{Systemic Absorption of Topical Treatments for AD}

In a pharmacokinetic study in children treated with hydrocortisone cream $1 \%$ (no occlusion), an increase of cortisol plasma levels over baseline of $77-967 \mathrm{ng} / \mathrm{ml}$ (212-2,669 nmol/l) has been reported, with HPA axis suppression observed in $38 \%$ of these patients [52]. In another study of hydrocortisone cream $1 \%$ in adults with widespread $\mathrm{AD}$ (at least 50\% BSA affected), plasma cortisol levels increased over baseline to up to $889 \mathrm{nmol} / 1$ [53]. These data indicate the potential for significant absorption of even low-potency topical corticosteroids in patients with $\mathrm{AD}$.
More recently developed topical corticosteroids seem to be associated with lower plasma levels. In a study of fluticasone propionate cream $0.05 \%$, plasma levels of fluticasone ranged between 0.07 and $0.39 \mathrm{ng} / \mathrm{ml}$. Although the medication was applied under occlusion, thus enhancing skin penetration, this effect was countered by the fact that the study was conducted in healthy volunteers where an intact skin barrier function may limit absorption [54]. Because the biological effect of fluticasone propionate is higher than the equimolar amount of hydrocortisone acetate, it is not surprising that some cases of HPA axis suppression were reported with fluticasone propionate cream $0.05 \%$. In a study in children as young as 3 months with moderate to severe and extensive AD $(64 \%$ BSA treated at baseline), only 2 children of the 43 enrolled exhibited HPA axis suppression [55]. Using more potent topical corticosteroids, HPA axis suppression is achieved in most patients, as reported for clobetasol propionate lotion $0.05 \%$, where $55 \%$ of $\mathrm{AD}$ patients had measurable HPA axis suppression after 2 weeks [56]. An expert discussion on the risk of HPA axis suppression with the United States Food and Drug Administration (FDA) (FDA-AC, March 24, 2005) noted that the level of sensitivity of the current HPA axis tests is only $70 \%$ (leaving $30 \%$ of cases undiagnosed), and that an undiagnosed HPA axis suppression carries the risk of 'sudden death'. The risk, however, is extremely low and is clinically acceptable as long as topical corticosteroids are used under supervision of a physician [57].

Due to its high lipophilicity, pimecrolimus penetrates into the skin, but its absorption through the skin into the systemic circulation is very low, lower than tacrolimus and much lower than steroids [58]. For rat, pig, and human skin, pimecrolimus demonstrated a 9- to 10-fold lower permeation through skin in vitro than tacrolimus when comparing identical solution of both compounds. Similar results were obtained using the marketed Elidel ${ }^{\circledR}$ cream (Novartis Pharmaceuticals Corporation, East Hanover, N.J., USA) and Protopic ${ }^{\circledR}$ ointments (Fujisawa Healthcare) [59]. The permeation rates through human skin measured in vitro were found to be lower with pimecrolimus than with tacrolimus, with pimecrolimus permeation rates lower than tacrolimus $0.1 \%$ ointment by a factor of about 6 .

When pimecrolimus cream $1 \%$ is applied to the skin, very little enters the systemic circulation (fig. 4) [60]. The systemic absorption of pimecrolimus cream $1 \%$ has been extensively evaluated in children and adults with moderate to severe $\mathrm{AD}[38,61-63]$. In pharmacokinetic studies of children (75 patients and 366 sam- 
ples) with up to $92 \%$ BSA affected, $67 \%$ of samples had pimecrolimus blood concentrations below $0.5 \mathrm{ng} / \mathrm{ml}$ and $97 \%$ of blood concentrations were in the range of $<0.5-2.0 \mathrm{ng} / \mathrm{ml}$.

In most patients in whom blood concentrations of pimecrolimus have been measured, the concentration of pimecrolimus was too low to allow the calculation of the area under the concentration-time curve (AUC) or the sampling scheme was not adequate [64]. In 8 of 20 pediatric patients (2-14 years of age) with a suitable blood sampling scheme, the $\mathrm{AUC}_{(0-24 \mathrm{~h})}$ ranged from 10.8 to $37.6 \mathrm{ng} \cdot \mathrm{h} / \mathrm{ml}$. The mean AUC in children (including infants) was $22.5 \mathrm{ng} \cdot \mathrm{h} / \mathrm{ml}$. In adults, the $\mathrm{AUC}_{(0-24 \mathrm{~h})}$ ranged from 5.0 to $22.8 \mathrm{ng} \cdot \mathrm{h} / \mathrm{ml}$, with a mean $\mathrm{AUC}_{(0-24 \mathrm{~h})}$ of $11.7 \mathrm{ng} \cdot \mathrm{h} / \mathrm{ml}$ [only 10 of 30 patients had measurable $\left.\mathrm{AUC}_{(0-24 \mathrm{~h})}\right]$ [65].

Early pharmacokinetics studies of tacrolimus $0.1 \%$ ointment in 49 adult $\mathrm{AD}$ patients showed that tacrolimus can be absorbed through the skin and enter the systemic circulation, with maximum blood concentrations ranging from undetectable to $20 \mathrm{ng} / \mathrm{ml}$ (possibly a patient with Netherton syndrome; see below). Most patients (45 of 49), however, had peak blood concentrations less than $5 \mathrm{ng} / \mathrm{ml}$. The results from a pharmacokinetic study of tacrolimus ointment $0.1 \%$ in 20 pediatric AD patients (aged 6-13 years) showed peak tacrolimus concentrations below $1.6 \mathrm{ng} / \mathrm{ml}$ in all patients $[66,67]$.

In a study by Harper et al. [68], the pharmacokinetics of tacrolimus were studied in 39 pediatric patients (aged 6-12 years) with moderate to severe AD, affecting 11$94 \%$ BSA. The systemic exposure of tacrolimus tended to increase as a larger affected BSA was treated: on day 1 of treatment for patients with affected BSA $\leq 1,500 \mathrm{~cm}^{2}$, the mean $\mathrm{AUC}_{(0-24 \mathrm{~h})}$ was $5.2 \mathrm{ng} \cdot \mathrm{h} / \mathrm{ml}$; for affected $\mathrm{BSA}>1,500$ and $\leq 3,000 \mathrm{~cm}^{2}$, the mean $\mathrm{AUC}_{(0-24 \mathrm{~h})}$ was $17.5 \mathrm{ng} \cdot \mathrm{h} / \mathrm{ml}$, and for affected BSA $>3,000$ and $\leq 5,000 \mathrm{~cm}^{2}$, the mean $\mathrm{AUC}_{(0-24 \mathrm{~h})}$ was $11.0 \mathrm{ng} \cdot \mathrm{h} / \mathrm{ml}$. The corresponding values on day 14 were $3.3,15.4$ and $11.4 \mathrm{ng} \cdot \mathrm{h} / \mathrm{ml}$.

The skin lesions in patients with Netherton syndrome represent a therapeutic challenge as the skin barrier function in these patients is significantly impaired, thus increasing absorption of any topically applied treatment. Tacrolimus ointment $0.1 \%$, when used in children with Netherton syndrome, induced blood levels (up to $37 \mathrm{ng} /$ $\mathrm{ml}$ ) well within or even above the range of those observed with orally administered Prograf for transplantation [69], establishing the potential for systemic immunosuppression with tacrolimus ointment in children with severely impaired skin barrier function. In contrast, pimecrolimus cream used in Netherton syndrome (99\% BSA treated) demonstrated blood levels below $2.4 \mathrm{ng} / \mathrm{ml}$ over the whole treatment period [70].

\section{Tacrolimus versus Pimecrolimus in Transplant Models}

A number of transplantation models in animals are available to assess the efficacy of a drug to provide systemic immunosuppression. In one model, a rat model of graft-versus-host reaction [71-73], injecting MHC-mismatched spleen cells into the hind foot pad of the rat caused a graft-versus-host reaction and lymph node enlargement near the site of injection. The doses (subcutaneous application) required to inhibit 50\% swelling were 66 times greater for pimecrolimus $(20 \mathrm{mg} / \mathrm{kg})$ than for tacrolimus $(0.3 \mathrm{mg} / \mathrm{kg})$ and 8 times greater than for cyclosporine A (CyA; $2.5 \mathrm{mg} / \mathrm{kg})$.

In another rat model of immunosuppression, pimecrolimus was found to be 48 times less effective than tacrolimus (subcutaneous application) for inhibiting the production of IgM anti-sheep antibodies when rats were injected with sheep red blood cells [71, 73]. Furthermore, in a rat model of allogeneic kidney transplantation, the oral pimecrolimus dose required for 100-day survival was $15.6 \mathrm{mg} / \mathrm{kg}$ compared with only $5.0 \mathrm{mg} / \mathrm{kg}$ of CyA and $1 \mathrm{mg} / \mathrm{kg}$ of tacrolimus [71-73]. The ability to achieve systemic immunosuppression in this model was 3 and 15 times less for oral pimecrolimus than for CyA and tacrolimus, respectively. These experiments in animals demonstrate that systemic exposure to pimecrolimus (following oral or subcutaneous application) is significantly less effective in suppressing the systemic immune system than other calcineurin inhibitors. Consistent with these findings, tacrolimus and $\mathrm{CyA}$, but not pimecrolimus, provide sufficient immunosuppression to be used clinically to prevent organ rejection/graft-versus-host disease after transplantation.

In contrast to the above-described studies in models of systemic immunosuppression, oral pimecrolimus was shown to be as effective as tacrolimus in inhibiting skin inflammation in mice and rats. Interestingly, in these experiments, the draining lymph nodes were not affected regarding primary immune response, weight, number, and functionality of lymph node cells, as was seen with tacrolimus [74]. 


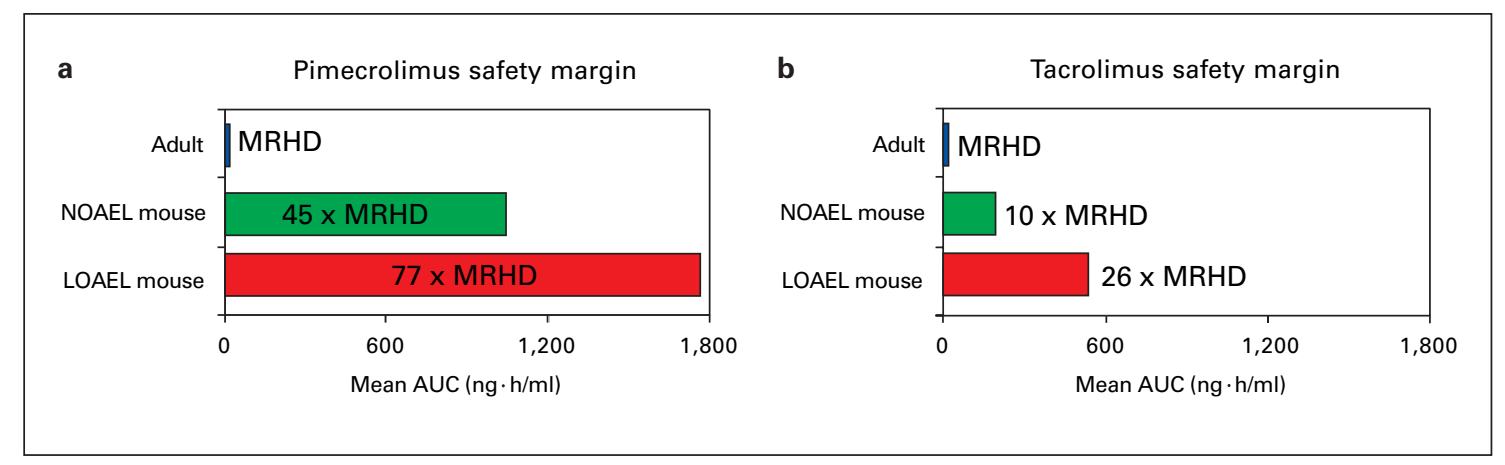

Fig. 5. Mean AUCs of tacrolimus and pimecrolimus in animal and human studies. According to regulatory ICH Guidelines, a NOAEL of 25 times MRHD (average exposure at the maximally recommended dose) or greater represents an adequate safety margin. a No malignancies were observed with exposure to pimecrolimus at 45 times the MRHD; at 77 times the MRHD lymphoma was seen. b In murine toxicology studies, no malignancies were observed with exposure to tacrolimus at 10 times the MRHD; at 26 times the MRHD lymphoma was seen $[65,67,77]$.

\section{Carcinogenicity Studies with Pimecrolimus and Tacrolimus}

As with all recently developed treatments, pimecrolimus and tacrolimus have been tested in numerous animal studies designed specifically to further explore the toxicity of the molecule and increase drug exposure to observe toxic effects. In dermal toxicology studies in rodents, pimecrolimus dissolved in an ethanolic solution (enhancing penetration through the skin) was applied to mice topically, administered continuously over 104 weeks (the life span of a mouse), resulting in a mean daily exposure $\left[\mathrm{AUC}_{(0-24 \mathrm{~h})}\right]$ of $1,040 \mathrm{ng} \cdot \mathrm{h} / \mathrm{ml}$. No drug-related malignancies were observed, establishing a non-observed adverse event level (NOAEL) in rodents (fig. 5a) $[64,65,75]$ In a similar study in mice using a higher dose achieving an $\mathrm{AUC}_{(0-24 \mathrm{~h})}$ of $\sim 1,770 \mathrm{ng} \cdot \mathrm{h} / \mathrm{ml}$, lymphoproliferative changes (including lymphoma) were observed after 13 weeks [64]. To further explore the toxicity profile of the molecule in an aim to develop an oral formulation of pimecrolimus for the treatment of psoriasis, the compound was administered orally in cynomolgus monkeys. At a dose of $15 \mathrm{mg} / \mathrm{kg} / \mathrm{day}$, animals reached an average systemic exposure of $\sim 1,200 \mathrm{ng} \cdot \mathrm{h} /$ $\mathrm{ml}$. After 39 weeks, 1 of 8 monkeys developed lymphoproliferative disease, indicating that oral administration at a dose of $15 \mathrm{mg} / \mathrm{kg} /$ day approaches a threshold for systemic immunosuppression, thus allowing the development of lymphoproliferative disorders $[65,75]$. Similarly, tacrolimus doses of $10 \mathrm{mg} / \mathrm{kg} /$ day resulted in lymphoproliferative changes in certain cynomolgus monkeys after 90 days [76]. The results in monkeys confirm the potential observed previously in rodents for producing lymphoproliferative disease upon sustained and prolonged exposure to high doses well above 25 times the average exposure at the maximally recommended human dose (referred to as MRHD), after topical pimecrolimus cream $1 \%$.

Dermal toxicology studies with tacrolimus ointment indicate a NOAEL at an $\left.\mathrm{AUC}_{(0-24} \mathrm{h}\right)$ of $189 \mathrm{ng} \cdot \mathrm{h} / \mathrm{ml}$, while lymphomas were noted in mice at $530 \mathrm{ng} \cdot \mathrm{h} /$ $\mathrm{ml}$, suggesting a threshold level at $\mathrm{AUC}_{(0-24 \mathrm{~h})}$ above $200 \mathrm{ng} \cdot \mathrm{h} / \mathrm{ml}$ (fig. 5b) [66, 77, 78].

In order to compare the toxicity profiles of tacrolimus and pimecrolimus, a standardized reference using the mean $\mathrm{AUC}_{(0-24 \mathrm{~h})}$ of all available AUCs from human pharmacokinetics studies can be established. In adults, the MRHD [ $\mathrm{AUC}_{(0-24 \mathrm{~h})}$ ] of tacrolimus is $20.4 \mathrm{ng} \cdot \mathrm{h} / \mathrm{ml}$ [77] in a particular study, and $23 \mathrm{ng} \cdot \mathrm{h} / \mathrm{ml}$ for pimecrolimus. Compared to this baseline, the NOAEL for tacrolimus established in dermal toxicity studies is $\sim 10$ times the MRHD [AUC ${ }_{(0-24 \mathrm{~h})}$ ] and for pimecrolimus it is $\sim 45$ times the MRHD. The lowest observed adverse event levels (LOAELs) established in the same model are $\sim 26$ times the MRHD for tacrolimus and $\sim 77$ times the MRHD for pimecrolimus (see fig. 5). (In cynomolgus monkeys, the LOAEL for oral pimecrolimus is $\sim 52$ times the MRHD).

Toxicology data suggest an increased safety margin for pimecrolimus compared with tacrolimus, which may become clinically relevant in cases of extensive and/or prolonged use of a topical calcineurin inhibitor, especially in children. 


\section{Clinical Experience with Topical Calcineurin Inhibitors}

\section{Pimecrolimus Cream}

In clinical studies, approximately 20,000 patients have been treated with pimecrolimus cream $1 \%$, including nearly 3,000 infants and over 7,000 children [65]. In clinical practice, over 5 million patients have been treated, of which nearly 2 million are below the age of 5 years. The average patient in clinical practice is treated intermittently for approximately 45 days per year and uses less than $2 \mathrm{~g}$ of pimecrolimus cream $1 \%$ per day [65].

Pimecrolimus cream 1\% has been studied in short-and long-term vehicle-controlled trials in infants, children, and adults. In 5 short-term studies, pimecrolimus cream $1 \%$ applied twice daily for 3-6 weeks was effective at controlling the signs and symptoms of $\mathrm{AD}$ in patients with predominantly moderate disease, using the Atopic Dermatitis Severity Index, Investigator Global Assessment, or Eczema Area and Severity Index (EASI) severity scores as endpoints [25,79-82]. In long-term studies of up to 1 year, pimecrolimus cream $1 \%$ applied twice daily as needed reduced AD flares and thus reduced the need for topical corticosteroids $[35,37,79,83]$.

\section{Tacrolimus Ointment}

In clinical studies, including post-marketing studies, more than 20,000 patients have been treated with tacrolimus ointment 0.03 and $0.1 \%$. Of those, more than 7,500 were pediatric patients. Over 1.7 million patients have been treated with tacrolimus ointment in clinical practice since 2001 [78].

In several short-term studies, tacrolimus ointment has been shown to be an effective treatment for AD in adults and children [30, 31, 33, 34, 84]. Patients treated with tacrolimus ointment, 0.03 and $0.1 \%$ applied twice daily for up to 6 weeks showed improvement in outcomes such as modified EASI and Investigator Global AD Assessment. In a 1 -year study, tacrolimus ointment $0.1 \%$ applied twice daily to areas of actively diseased skin was shown to be effective as assessed by modified EASI and Investigator Global Assessment, with ointment use decreasing over time [32].

\section{Lack of Evidence of Systemic Immunosuppression with Pimecrolimus Cream}

In a 2 -year study, the use of pimecrolimus cream $1 \%$ was evaluated to determine if there were any effects on

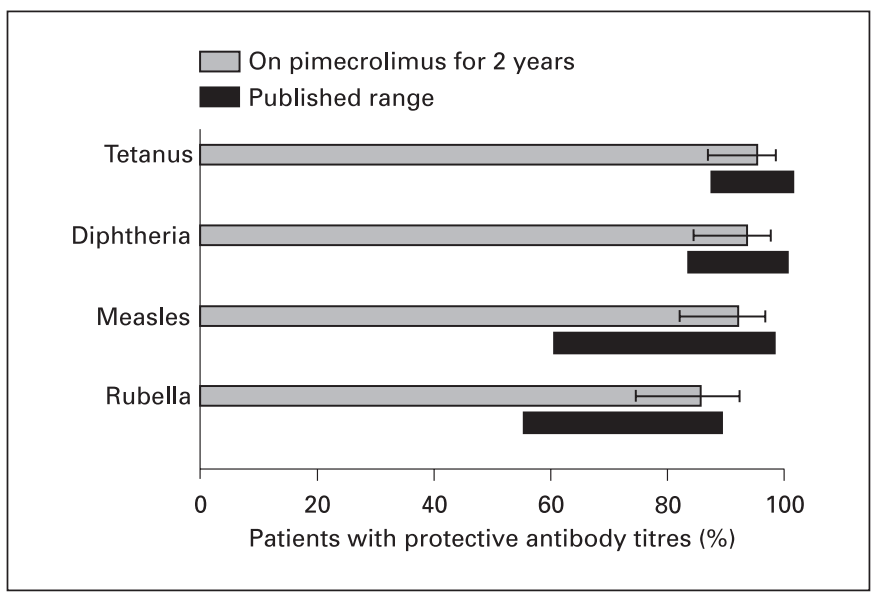

Fig. 6. No effect of pimecrolimus treatment on vaccination response (B cell mediated). Overall seropositivity rate to tetanus, diphtheria, measles, and rubella in patients treated with pimecrolimus for 2 years compared with corresponding seropositivity range reported in a general, age-matched population. Error bars: 95\% CI. Adapted with permission from Papp et al. [85].

the ability of children to mount an immune response after vaccination [85]. Ninety-one patients who had been treated with pimecrolimus for up to 2 years were vaccinated against diphtheria, measles, rubella, and tetanus. The mean BSA involved was $27.6 \%$ at baseline, with a median number of days of application of 377.5. There were no differences in seropositivity for these vaccines among those treated or untreated with pimecrolimus cream 1\% (fig. 6) [85]. These results demonstrate that pimecrolimus cream $1 \%$ does not interfere with the development of immune responses to vaccines. This has also been shown to be true for tacrolimus ointment $0.03 \%$ in a similar study of pneumococcal seroconversion. The 23 observed patients had moderate to severe AD, with a mean BSA affected of $28.1 \%$, and $91 \%$ had a greater than 4 -fold increase in titer for at least 4 of 12 pneumococcal serotypes [86].

Cell-mediated, delayed-type hypersensitivity reaction against a range of antigens is a common method of assessing immunocompetence. Delayed-type hypersensitivity was used to test immune function in one study of pimecrolimus cream $1 \%$ with a total of 112 subjects who completed 1 year of treatment with pimecrolimus cream $1 \%$ (82 pimecrolimus cream 1\%; 30 vehicle), and one study of tacrolimus ointment $0.1 \%$ with 56 subjects evaluated after 6 months and 15 subjects evaluated after 1 year [32, 37]. The results of both studies suggest that use of pimecrolimus cream $1 \%$ or tacrolimus $0.1 \%$ has no effect on the 
Fig. 7. Data from randomized clinical studies of pimecrolimus show a lack of evidence of an increased risk of malignancies. From 19,000 patients on pimecrolimus, 2 malignancies were reported, both in elderly patients. In the 4,000-patient control group, 5 malignancies were observed, including a case of acute lymphatic leukemia and a case of malignant melanoma [60]. SCC = Squamous cell carcinoma; ALL = acute lymphatic leukemia. Data as of January 2005.

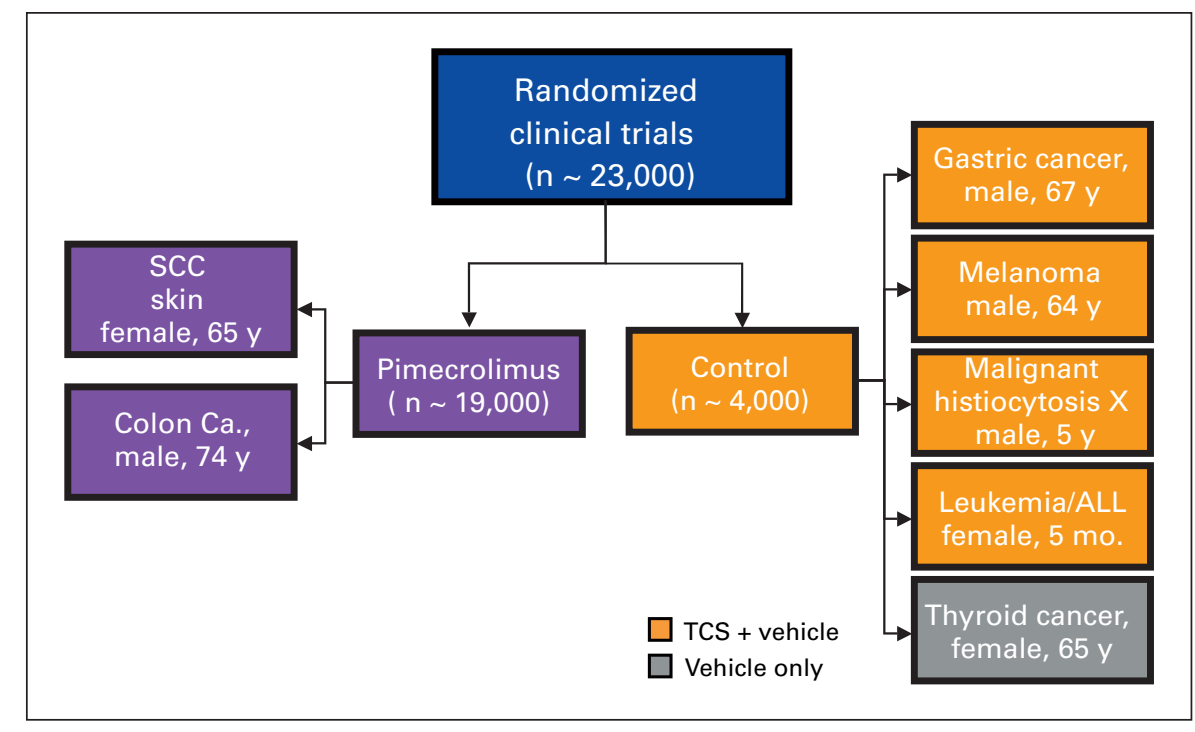

ability to develop a normal $\mathrm{T}$ cell-mediated immune response.

In a study that included 76 children who received pimecrolimus for 2 years, pimecrolimus cream $1 \%$ was effective for reducing the EASI by a mean of $70.8 \%$ from baseline [40]. In addition, pimecrolimus $1 \%$ was safe and well tolerated in these children. Compared with the first year of the study, common childhood infections declined over time and throughout the second year of treatment with pimecrolimus cream $1 \%$. The decreased rate of infections after long-term treatment in this study suggests that pimecrolimus cream $1 \%$ does not have an adverse effect on the systemic immune system over time. With respect to malignancies, significantly less were reported in patients using pimecrolimus ( 1 case per 9,500 patients) compared with patients treated with topical corticosteroids or placebo ( 1 case per 800 patients). The malignancies reported in patients using pimecrolimus in clinical trials were 1 case of colon cancer and 1 case of squamous cell carcinoma, both in patients above 65 years of age (fig. 7) [60, 65].

\section{Experience with Topical Calcineurin Inhibitors in Clinical Practice: Spontaneous Reports of Adverse Events}

The FDA collects spontaneous reports of drug-related adverse events on a regular basis, and those reported for topical calcineurin inhibitors were presented in September and October of 2004 by the Office of Drug Safety [87,
88]. While no immunosuppression-related malignancies (see below) attributable to the use of topical calcineurin inhibitors were reported, a case report of sepsis in a child with severe $\mathrm{AD}$ who had used tacrolimus ointment $0.1 \%$ in large amounts was pointed out. Although sepsis in a child with severe $\mathrm{AD}$ is possibly related to the underlying disease, the detection of a blood level of tacrolimus of $3.5 \mathrm{ng} / \mathrm{ml}$, measured 2 weeks after stopping administration of tacrolimus, is noteworthy.

\section{Lymphoproliferative Disease in Patients with Systemic Immunosuppression: A Different Clinical Entity in Humans}

Three types of conditions have been associated with immunosuppression-related lymphoproliferative diseases in humans: (1) congenital immunodeficiencies; (2) acquired immunodeficiencies, and (3) post-transplantation immunodeficiency/suppression.

\section{Congenital Immunodeficiencies}

Virtually all congenital immunodeficiency syndromes that affect $T$ cells confer an increased risk of lymphoproliferative disease [89-91]. This risk may be considerable, rising to approximately $10 \%$ in patients with Wiskott-Aldrich syndrome and up to $30 \%$ in patients with X-linked lymphoproliferative disease. Patients with the more frequently observed diagnosis of common variable immunodeficiency have been reported to have a 23- to 100-fold increase in risk of malignant lymphoma [89, 91, 92]. Sig- 
nificant proportions of these immunodeficient patients may have eczema or chronic dermatitis as part of the underlying disease [93]. Management of the eczema frequently antedates final diagnosis, and immunodeficiency diseases may go undiagnosed for long periods of time (such as in the case of common variable immunodeficiency). Thus, consideration of underlying immunodeficiency and predisposition to lymphoma should be considered when lymphoproliferative disorders develop in individuals, particularly children, with severe or refractory eczema.

\section{Acquired Immunodeficiencies}

Acquired immunodeficiencies are all associated with an increased risk of the development of lymphoproliferative disease, usually in the context of immune suppression with some secondary stimulus, such as acquisition or reactivation of a viral infection with agents such as HIV, EBV, cytomegalovirus, herpes simplex virus 8 , or hepatitis virus $C[94,95]$. Use of anti-T-cell antibodies in solid organ and hematopoietic stem cell transplantation is also associated with an increased risk of lymphoproliferative disease $[96,97]$. While the risk may be conferred by inducing lymphopenia, it is also noteworthy that these agents may exert direct mitogenic effects [98].

\section{Post-Transplantation Immunodeficiency/Suppression}

The most pertinent data related to the potential relationships of topical immunosuppressants to immunodeficiency-related lymphoproliferation disease (IRLD) emerge from an analysis of individuals with post-transplant lymphoproliferative disease (PTLD). The incidence of lymphomas after hematopoietic stem cell transplantation is very low $(0-0.7 \%)[94]$ in patients (pediatric and adult) who are related and HLA-matched, despite aggressive immunosuppressive conditioning regimens containing agents such as cyclophosphamide, fludarabine, and total body irradiation as well as post-hematopoietic stem cell transplantation systemic administration of calcineurin inhibitors, methotrexate, mycophenolate, and corticosteroids. The incidence rises substantially when the donor $\mathrm{T}$ cells are removed (especially in the absence of concomitant B cell depletion) and with increasing HLA disparity. For example, the relative risk of early onset PTLD appears to be 4-fold greater with HLA disparity and 13-fold greater with T cell depletion of stem cells [99]. PTLD almost uniformly occurs within the first 8 months, with a median time of 3 months. This contrasts with the timing in solid organ transplantation recipients, who can develop lymphomas early (4-8 months) or late ( $>1$ year) [94].

Immunomodulation and Safety of Topical Calcineurin Inhibitors
In contrast, the reported incidence of PTLD in solid organ transplantation patients ranges from 2 to $60 \%$ and is dependent on the type of organ transplanted. Generally, there are more cases of PTLD with small bowel transplantations than with heart, lung, or liver transplantations. Kidney transplantation patients are least affected [94]. It is hypothesized that small bowel transplants have the highest rate of PTLD (approximately 30\% in pediatric patients) due to the high concentration of lymphocytes in this tissue and the likelihood of potential transfer of EBVinfected donor lymphocytes to the often seronegative pediatric patient. Regardless of organ type, there is a general relationship between the intensity of immunosuppression and the risk of PTLD. The majority of PTLD described has been $\mathrm{B}$ cell phenotype, with a reported rate of $\mathrm{T}$ cell disease of only approximately $10 \%$, even with very long follow-ups [100, 101].

The concern that topical calcineurin inhibitors would cause lymphoproliferation can be addressed best with what we understand to date about IRLD. This information has been accumulated over many years of observing patients with acquired and congenital immunodeficiency. In fact it is reassuring, rather than disturbing, that the cases of lymphoma observed in primate animal studies were histologically consistent with a virus-related lymphoproliferative state after prolonged, high-dose immunosuppression [65]. Thus, if these lesions represent IRLD associated with pimecrolimus, then the mechanism and results fit the model of IRLD found with other high-dose immunosuppressants in humans.

However, current topical pimecrolimus use in children and adults, which consists of intermittent use of a poorly absorbed drug, is not consistent with IRLD models. First, neither the complexity nor the intensity of the topical immunosuppression observed with pimecrolimus cream $1 \%$ is sufficient to be plausibly related to IRLD. Even if intermittent detectable systemic levels are occasionally achieved in some patients [38], this does not represent a risk in humans, based on the experience with sustained high systemic levels of the calcineurin inhibitor CyA in patients with aplastic anemia (i.e., patients who, like those with $\mathrm{AD}$, do not suffer from any of the other complications associated with a transplant). In these patients, systemic exposure to CyA alone is insufficient to give rise to increased lymphoma risk $[102,103]$. This observation can also be extrapolated to negate the argument that draining lymph nodes might have higher levels of pimecrolimus than the skin; it is implausible that levels in the lymph nodes of topically treated patients would be greater than that found in patients with rheumatologic 
diseases or aplastic anemia who are on daily oral calcineurin inhibitors and in whom the therapeutic levels are routinely maintained for months or even years.

Second, the association of EBV with all types of IRLD is well established [89], and there may have been a viral association in the non-human primate case of lymphoma [75]. No such association with EBV has been reported for topical calcineurin inhibitor-treated cases to date. It is likely that there would be an association with EBV if these were indeed cases of IRLD.

Third, the range of histologic appearance (and progression from atypia to frank lymphoma) of IRLD lesions in humans has been characterized and reported by many groups [94]. No such range or progression is evident in the reported topical calcineurin inhibitor-treated cases [88]. It is implausible that in this group of patients all lesions would have been diagnosed in their most advanced state. In the IRLD literature, a preponderance of B cell disease is reported while $\mathrm{T}$ cell disease is rare [90]. This is the opposite of what has been seen in the spontaneous cases reported to date. If T cell PTLD occurs, it generally does so after 8-10 years of continued immunosuppression $[94,95]$, not after the relatively short time that these patients were treated. The literature discloses that $\mathrm{T}$ cell PTLD is aggressive and does poorly under treatment. All patients with lymphoma who use pimecrolimus cream $1 \%$ that have been reported to date appear to be responsive to therapy and are doing well. If these reports indeed were representative of pimecrolimus-induced IRLD, it would be difficult to explain why virtually every signature characteristic of IRLD described in the literature fails to be echoed in them.

Finally, it is important to recognize that patients with PTLD have had meticulous pre-transplant as well as careful and frequent post-transplant assessments. Thus they are known to be lymphoma-free at transplant, their clinical course and drug utilization is well understood, and, therefore, attribution of lymphoma to immunosuppression associated with transplant is likely correct. In contrast, some of the reported cases of putative pimecrolimus- or tacrolimus-related IRLD are very suggestive of underlying disorders (e.g., peripheral $\mathrm{T}$ cell lymphoma) mistaken for $\mathrm{AD}$, with the correct diagnosis being made only after treatment had been initiated. Careful assessment of pre-existing lymphoma risk (particularly in children who may have congenital immunodeficiency and associated eczema) and evaluation of adults for pre-existing syndromes such as cutaneous $\mathrm{T}$ cell lymphoma and mycosis fungoids is therefore essential if attribution and understanding of risk is to be accurately ascertained.

\section{Summary}

$\mathrm{AD}$ is a prevalent disease in young children that can have a profound impact on physical and social well-being, and is often the first step in the atopic march. The impaired Th1 response that is seen in atopic children is qualitatively similar to the one seen in healthy infants, but is more pronounced. In order for a mature Th 1 response to develop, APC and especially DC function is important. Factors that adversely affect the viability and function of these cells have the potential to delay or suppress the maturation of the immune system in young children, thereby promoting a persistent Th2-dominant response pattern.

Topical corticosteroids, in contrast to topical calcineurin inhibitors, reduce viability and function of LCs/DCs of skin and lymph nodes, contributing to a reduction in Th1-promoting cytokines (e.g., IL-12). These recently acquired immunological insights raise further questions about the use of topical corticosteroids in young children. Alternative topical treatments, such as topical calcineurin inhibitors, act more selectively and may provide advantages over older treatments. Within the class of available topical calcineurin inhibitors, pimecrolimus cream $1 \%$ seems to exhibit a larger safety margin than tacrolimus ointment.

In contrast to the experience with topical pimecrolimus cream and tacrolimus ointment, systemically administered tacrolimus and CyA have been shown to induce systemic immunosuppression, thus increasing the risk of malignancies in patients having undergone organ transplantation. However, the degree of systemic immunosuppression required is not attainable with topical calcineurin inhibitors. In over 3 years of usage in more than 5 million patients using pimecrolimus cream, and over 1.7 million patients using tacrolimus ointment, the safety of both of these treatments has been established.

\section{Conclusions}

Today's immunology insights and data suggest an advantage of topical calcineurin inhibitors over topical corticosteroids for the use in young children. Data suggest that within the class of topical calcineurin inhibitors, pimecrolimus cream exhibits a larger safety margin than tacrolimus ointment. 


\section{References}

1 Kay J, Gawkrodger DJ, Mortimer MJ, Jaron AG: The prevalence of childhood atopic ecze$\mathrm{ma}$ in a general population. $\mathrm{J}$ Am Acad Dermatol 1994;30:35-39.

2 Spergel JM, Paller AS: Atopic dermatitis and the atopic march. J Allergy Clin Immunol 2003;112(6 suppl):S118-S127.

-3 Leung DY, Boguniewicz M, Howell MD, Nomura I, Hamid QA: New insights into atopic dermatitis. J Clin Invest 2004; 113:651-657.

4 Williams HC, Strachan DP: The natural history of childhood eczema: observations from the British 1958 birth cohort study. Br J Dermatol 1998;139:834-839.

5 Wuthrich B: Clinical aspects, epidemiology, and prognosis of atopic dermatitis. Ann Allergy Asthma Immunol 1999;83:464-470.

-6 Paller AS, McAlister RO, Doyle JJ, Jackson A: Perceptions of physicians and pediatric patients about atopic dermatitis, its impact, and its treatment. Clin Pediatr (Phila) 2002;41: 323-332.

7 Dahl RE, Bernhisel-Broadbent J, ScanlonHoldford S, Sampson HA, Lupo M: Sleep disturbances in children with atopic dermatitis. Arch Pediatr Adolesc Med 1995; 149:856860.

-8 Bender BG, Leung SB, Leung DY: Actigraphy assessment of sleep disturbance in patients with atopic dermatitis: an objective life quality measure. J Allergy Clin Immunol 2003;111: 598-602.

-9 Breuer K, Werfel T, Kapp A: Safety and efficacy of topical calcineurin inhibitors in the treatment of childhood atopic dermatitis. Am J Clin Dermatol 2005;6:65-77.

-10 Bergmann RL, Edenharter G, Bergmann KE, Forster J, Bauer CP, Wahn V, Zepp F, Wahn $\mathrm{U}$ : Atopic dermatitis in early infancy predicts allergic airway disease at 5 years. Clin Exp Allergy 1998;28:965-970.

-11 Castro-Rodriguez JA, Holberg CJ, Wright AL, Martinez FD: A clinical index to define risk of asthma in young children with recurrent wheezing. Am J Respir Crit Care Med 2000; 162:1403-1406.

-12 Gustafsson D, Sjoberg O, Foucard T: Development of allergies and asthma in infants and young children with atopic dermatitis - a prospective follow-up to 7 years of age. Allergy 2000;55:240-245.

13 Cookson W: The immunogenetics of asthma and eczema: a new focus on the epithelium. Nat Rev Immunol 2004;4:979-988.

14 Hamid Q, Boguniewicz M, Leung DY: Differential in situ cytokine gene expression in acute versus chronic atopic dermatitis. J Clin Invest 1994;94:870-876.

-15 Novak N, Bieber T, Leung DY: Immune mechanisms leading to atopic dermatitis. J Allergy Clin Immunol 2003;112(6 suppl):S128-S139.
6 Rowe J, Macaubas C, Monger TM, Holt BJ, Harvey J, Poolman JT, Sly PD, Holt PG: Antigen-specific responses to diphtheria-tetanusacellular pertussis vaccine in human infants are initially $\mathrm{Th} 2$ polarized. Infect Immun 2000;68:3873-3877.

17 Miyawaki T, Seki H, Taga K, Sato H, Taniguchi N: Dissociated production of interleukin-2 and immune (gamma) interferon by phytohaemagglutinin stimulated lymphocytes in healthy infants. Clin Exp Immunol 1985;59:505-511.

18 Sorg RV, Kogler G, Wernet P: Identification of cord blood dendritic cells as an immature CD11c- population. Blood 1999;93:23022307.

19 Hunt DW, Huppertz HI, Jiang HJ, Petty RE: Studies of human cord blood dendritic cells: evidence for functional immaturity. Blood 1994;84:4333-4343.

20 Dewar AL, Doherty KV, Woods GM, Lyons $\mathrm{AB}$, Muller HK: Acquisition of immune function during the development of the Langerhans cell network in neonatal mice. Immunology 2001;103:61-69.

21 Wollenberg A, Kraft S, Hanau D, Bieber T: Immunomorphological and ultrastructural characterization of Langerhans cells and a nov$\mathrm{el}$, inflammatory dendritic epidermal cell (IDEC) population in lesional skin of atopic eczema. J Invest Dermatol 1996; 106:446453.

22 Sulzberger MB, Witten VH, Smith CC: Hydrocortisone (compound F) acetate ointment in dermatological therapy. J Am Med Assoc 1953;151:468-472.

23 Leung DY, Bloom JW: Update on glucocorticoid action and resistance. J Allergy Clin Immunol 2003;111:3-22.

24 Kalthoff FS, Chung J, Musser P, Stuetz A: Pimecrolimus does not affect the differentiation, maturation and function of human monocyte-derived dendritic cells, in contrast to corticosteroids. Clin Exp Immunol 2003; 133: 350-359.

-25 Hoetzenecker W, Ecker R, Kopp T, Stuetz A, Stingl G, Elbe-Bürger A: Pimecrolimus leads to an apoptosis-induced depletion of $\mathrm{T}$ cells but not Langerhans cells in patients with atopic dermatitis. J Allergy Clin Immunol 2005;115: 1276-1283.

-26 Hoetzenecker W, Meingassner JG, Ecker R, Stingl G, Stuetz A, Elbe-Burger A: Corticosteroids but not pimecrolimus affect viability, maturation and immune function of murine epidermal Langerhans cells. J Invest Dermatol 2004; 122:673-684.

-27 Aberer W, Romani N, Elbe A, Stingl G: Effects of physicochemical agents on murine epidermal Langerhans cells and Thy-1-positive dendritic epidermal cells. J Immunol 1986;136: 1210-1216.

28 Shapiro R: Tacrolimus in pediatric renal transplantation: a review. Pediatr Transplant 1998; 2:270-276.
29 Tanner JE, Alfieri C: The Epstein-Barr virus and post-transplant lymphoproliferative disease: interplay of immunosuppression, EBV, and the immune system in disease pathogenesis. Transpl Infect Dis 2001;3:60-69.

- 30 Paller AS, Lebwohl M, Fleischer AB Jr, Antaya R, Langley RG, Kirsner RS, Blum RR, Rico MJ, Jaracz E, Crowe A, Linowski GJ: Tacrolimus ointment is more effective than pimecrolimus cream with a similar safety profile in the treatment of atopic dermatitis: results from 3 randomized, comparative studies. J Am Acad Dermatol 2005;52:810-822.

-31 Boguniewicz M, Fiedler VC, Raimer S, Lawrence ID, Leung DY, Hanifin JM: A randomized, vehicle-controlled trial of tacrolimus ointment for treatment of atopic dermatitis in children. Pediatric Tacrolimus Study Group. J Allergy Clin Immunol 1998;102:637-644.

- 32 Reitamo S, Wollenberg A, Schopf E, Perrot JL, Marks R, Ruzicka T, Christophers E, Kapp A, Lahfa M, Rubins A, Jablonska S, Rustin M: Safety and efficacy of 1 year of tacrolimus ointment monotherapy in adults with atopic dermatitis. The European Tacrolimus Ointment Study Group. Arch Dermatol 2000;136:999_ 1006.

33 Reitamo S, Harper J, Bos JD, Cambazard F, Bruijnzeel-Koomen C, Valk P, Smith C, Moss C, Dobozy A, Palatsi R: $0.03 \%$ Tacrolimus ointment applied once or twice daily is more efficacious than $1 \%$ hydrocortisone acetate in children with moderate to severe atopic dermatitis: results of a randomized double-blind controlled trial. Br J Dermatol 2004; 150:554-562.

34 Ruzicka T, Bieber T, Schopf E, Rubins A, Dobozy A, Bos JD, Jablonska S, Ahmed I, Thestrup-Pedersen K, Daniel F, Finzi A, Reitamo S: A short-term trial of tacrolimus ointment for atopic dermatitis. European Tacrolimus Multicenter Atopic Dermatitis Study Group. N Engl J Med 1997;337:816-821.

- 35 Meurer M, Folster-Holst R, Wozel G, Weidinger G, Junger M, Brautigam M: Pimecrolimus cream in the long-term management of atopic dermatitis in adults: a six-month study. Dermatology 2002;205:271-277.

- 36 Leo HL, Bender BG, Leung SB, Tran ZV, Leung DY: Effect of pimecrolimus cream $1 \%$ on skin condition and sleep disturbance in children with atopic dermatitis. J Allergy Clin Immunol 2004;114:691-693.

- 37 Wahn U, Bos JD, Goodfield M, Caputo R, Papp K, Manjra A, Dobozy A, Paul C, Molloy S, Hultsch T, Graeber M, Cherill R, de Prost Y: Efficacy and safety of pimecrolimus cream in the long-term management of atopic dermatitis in children. Pediatrics 2002;110:e2.

38 Allen BR, Lakhanpaul M, Morris A, Lateo S, Davies T, Scott G, Cardno M, Ebelin ME, Burtin P, Stephenson TJ: Systemic exposure, tolerability, and efficacy of pimecrolimus cream $1 \%$ in atopic dermatitis patients. Arch Dis Child 2003;88:969-973. 
-39 Luger TA, Lahfa M, Folster-Holst R, Gulliver WP, Allen R, Molloy S, Barbier N, Paul C, Bos JD: Long-term safety and tolerability of pimecrolimus cream $1 \%$ and topical corticosteroids in adults with moderate to severe atopic dermatitis. J Dermatolog Treat 2004;15:169_ 178.

-40 Papp KA, Werfel T, Folster-Holst R, Ortonne JP, Potter PC, de Prost Y, Davidson MJ, Barbier N, Goertz HP, Paul C: Long-term control of atopic dermatitis with pimecrolimus cream $1 \%$ in infants and young children: a two-year study. J Am Acad Dermatol 2005;52:240246.

-41 Meurer M, Fartasch M, Albrecht G, Vogt T, Worm M, Ruzicka T, Altmeyer PJ, Schneider D, Weidinger G, Braeutigam M: Long-term efficacy and safety of pimecrolimus cream 1\% in adults with moderate atopic dermatitis. Dermatology 2004;208:365-372.

-42 Kempers S, Boguniewicz M, Carter E, Jarratt M, Pariser D, Stewart D, Stiller M, Tschen E, Chon K, Wisseh S, Abrams B: A randomized investigator-blinded study comparing pimecrolimus cream $1 \%$ with tacrolimus ointment $0.03 \%$ in the treatment of pediatric patients with moderate atopic dermatitis. J Am Acad Dermatol 2004;51:515-525.

43 Eichenfield LF, Lucky AW, Boguniewicz M, Langley RG, Cherill R, Marshall K, Bush C, Graeber M: Safety and efficacy of pimecrolimus (ASM 981) cream 1\% in the treatment of mild and moderate atopic dermatitis in children and adolescents. J Am Acad Dermatol 2002;46:495-504.

-44 Breuer K, Braeutigam M, Kapp A, Werfel T: Influence of pimecrolimus cream $1 \%$ on different morphological signs of eczema in infants with atopic dermatitis. Dermatology 2004; 209:314-320

-45 Grassberger M, Baumruker T, Enz A, Hiestand P, Hultsch T, Kalthoff F, Schuler W, Schulz M, Werner FJ, Winiski A, Wolff B, Zenke G: A novel anti-inflammatory drug, SDZ ASM 981, for the treatment of skin diseases: in vitro pharmacology. Br J Dermatol 1999; 141:264 273.

-46 Bornhovd EC, Burgdorf WH, Wollenberg A: Immunomodulatory macrolactams for topical treatment of inflammatory skin diseases. Curr Opin Investig Drugs 2002;3:708-712.

- 47 Kalthoff FS, Chung J, Stuetz A: Pimecrolimus inhibits up-regulation of OX40 and synthesis of inflammatory cytokines upon secondary $\mathrm{T}$ cell activation by allogeneic dendritic cells. Clin Exp Immunol 2002; 130:85-92.

48 Winiski AP, Kalthoff F, Fichtinger P, Olt S, Schwendinger B, Weishaeupl C, Stuetz A: Human $\mathrm{T}$ cells are differentially susceptible to pimecrolimus and tacrolimus depending on their history of stimulation (abstract). J Invest Dermatol 2005; 124:A45.

49 Meingassner JG, Kowalsky E, Schwendinger $\mathrm{H}$, Elbe-Burger A, Stutz A: Pimecrolimus does not affect Langerhans cells in murine epidermis. Br J Dermatol 2003; 149:853-857.
Kuipers H, Heirman C, Hijdra D, Muskens F, Willart M, van Meirvenne S, Thielmans $\mathrm{K}$, Hoogsteden HC, Lambrecht BN: Dendritic cells retrovirally overexpressing IL-12 induce strong Th1 responses to inhaled antigen in the lung but fail to revert established Th2 sensitization. J Leukoc Biol 2004;76:10281038 .

51 Mainali ES, Kikuchi T, Tew JG: Dexamethasone inhibits maturation and alters function of monocyte-derived dendritic cells from cord blood. Pediatr Res 2005, March 17: E-pub ahead of print.

52 Turpeinen M, Salo OP, Leisti S: Effect of percutaneous absorption of hydrocortisone on adrenocortical responsiveness in infants with severe skin disease. Br J Dermatol 1986;115: 475-484.

53 Aalto-Korte K, Turpeinen M: Pharmacokinetics of topical hydrocortisone at plasma level after applications once or twice daily in patients with widespread dermatitis. Br J Dermatol 1995; 133:259-263.

54 Cutivate Cream $0.05 \%$ (prescribing information): Pittsburgh, Glaxosmithkline, 2002.

55 Friedlander SF, Hebert AA, Allen DB: Safety of fluticasone propionate cream $0.05 \%$ for the treatment of severe and extensive atopic dermatitis in children as young as 3 months. J Am Acad Dermatol 2002;46:387-393.

56 Clobex lotion $0.05 \%$ (prescribing information). Fort Worth, Galderma Laboratories, 2004

57 Department of Health and Human Services, FDA, CDER: Joint session with the nonprescription and dermatologic drugs advisory committee, vol 2. FDA 2, 1-330, 2004. http:// www.fda.gov/ohrms/dockets/ac/05/transcripts/2005-4099T1.htm

58 Billich A, Aschauer H, Aszodi A, Stuetz A: Percutaneous absorption of drugs used in atopic eczema: pimecrolimus permeates less through skin than corticosteroids and tacrolimus. Int J Pharm 2004;269:29-35.

59 Billich A, Aschauer H, Stuetz A: In vitro penetration/permeation of pimecrolimus and tacrolimus from their marketed formulations (Elidel and Protopic) (abstract). J Invest Dermatol 2004; 122:A40.

60 Hultsch T: Elidel (pimecrolimus) cream 1\% safety update February 2005. Internet, CS-10. 2005. http://www.fda.gov/ohrms/dockets/ ac/05/slides/2005-4089s2 02 02 Novartis\% 20Core $\% 20$ Safety $\% 20$ (CS).pdf.

61 Harper J, Green A, Scott G, Gruendl E, Dorobek B, Cardno M, Burtin P: First experience of topical SDZ ASM 981 in children with atopic dermatitis. Br J Dermatol 2001;144: 781-787.

62 Thaci D, Steinmeyer K, Ebelin ME, Scott G, Kaufmann R: Occlusive treatment of chronic hand dermatitis with pimecrolimus cream $1 \%$ results in low systemic exposure, is well tolerated, safe, and effective. An open study. Dermatology 2003;207:37-42.
63 Van Leent EJM, Ebelin ME, Burtin P, Dorobek B, Spuls PI, Bos JD: Low systemic exposure after repeated topical application of pimecrolimus (Elidel ${ }^{\circledR}$, SDZASM981) in patients with atopic dermatitis. Dermatology 2002;204:6368.

64 Elidel (prescribing information). East Hanover, Novartis Pharmaceuticals, 2004.

65 Drug Regulatory Affairs: Elidel (pimecrolimus) cream 1\%. NDA 21-302, 2005. http:// www.fda.gov/ohrms/dockets/ac/05/briefing/2005-4089b2.htm.

66 Hill B: Topical immunosuppressants (calcineurin inhibitors) - animal toxicology. http:// www.fda.gov/ohrms/dockets/ac/0 5 / slides/2005-4089s2 0106 Hill.ppt.

67 Protopic (package insert). Deerfield, Fujisawa, 2000.

68 Harper J, Smith C, Rubins A, Green A, Jackson K, Zigure S, Bourke J, Alomar A, Stevenson P, Foster C, Undre N: A multicenter study of the pharmacokinetics of tacrolimus ointment after first and repeated application to children with atopic dermatitis. J Invest Dermatol 2005; 124:695-699.

69 Allen A, Siegfried E, Silverman R, Williams ML, Elias PM, Szabo SK, Korman NJ: Significant absorption of topical tacrolimus in 3 patients with Netherton syndrome. Arch Dermatol 2001; 137:747-750.

70 Oji V, Beljan G, Beier K, Traupe H, Luger T: Topical pimecrolimus: a novel therapeutic option for Netherton syndrome. Abstract Eur Acad Dermatol Venereol 13th Congr, Florence, Italy, Nov 17-21, 2004.

71 Stuetz A, Grassberger M, Meingassner JG: Pimecrolimus (Elidel, SDZ ASM 981) -preclinical pharmacologic profile and skin selectivity. Semin Cutan Med Surg 2001;20:233241

72 Meingassner J, Hiestand P, Bigout M, Grassberger M, Schuurman H, Tanner M, Stuetz A SDZ ASM 981 is highly effective in animal models of skin inflammation, but has only low activity in models indicating immunosuppressive potential, in contrast to cyclosporin A and FK 506 (abstract). J Invest Dermatol 2001; $117: 532$.

73 Meingassner JG, Di Padova F, Hiestand P, Bigaud P, Grassberger M, Schuurman H, Tanner M, Stuetz A: Pimecrolimus (Elidel ${ }^{\circledR}$, SDZ ASM 981): highly effective in models of skin inflammation but low activity in models of immunosuppression (abstract). J Eur Acad Dermatol Venereol 2001; 15:214.

74 Meingassner JG, Fahrngruber H, Bavandi A Pimecrolimus inhibits the elicitation phase but does not suppress the sensitization phase in murine contact hypersensitivity, in contrast to tacrolimus and cyclosporine A. J Invest Dermatol 2003; 121:77-80.

75 Food and Drug Administration: Pharmacokinetics/toxicokinetics. Brief summary. 2005: 1-18. http://www.fda.gov/ohrms/dockets/ ac/05/briefing/2005-4089b2_01_07 Tox\%20Review\%20Redacted.pdf. 
76 Wijnen RM, Ericzon BG, Tiebosch AT, Buurman WA, Groth CG, Kootstra G: Toxicology of FK506 in the cynomolgus monkey: a clinical, biochemical, and histopathological study. Transpl Int 1992;5(suppl 1):S454-S458.

77 Food and Drug Administration: Protopic (tacrolimus) ointment. Center for Drug Evaluation and Research Application Number NDA 50777. 2005:1-51. http://www.fda.gov/cder/ foi/nda/2000/50777_protopic.htm.

78 Food and Drug Administration, Pediatric Advisory Committee: Discussion topic: risk evaluation, labeling, risk communication, and dissemination of information on potential cancer risk among pediatric patients treated for atopic dermatitis with topical dermatological immunosuppressants. 2005:1-30. http://www. fda.gov/ohrms/dockets/ac/05/briefing/20054089b2_02_02_Protopic\%20Fujisawa\%20bri efing.pdf.

79 Wellington K, Noble S: Pimecrolimus: a review of its use in atopic dermatitis. Am J Clin Dermatol 2004;5:479-495.

-80 Van Leent EJ, Graber M, Thurston M, Wagenaar A, Spuls PI, Bos JD: Effectiveness of the ascomycin macrolactam SDZ ASM 981 in the topical treatment of atopic dermatitis. Arch Dermatol 1998;134:805-809.

-81 Luger T, Van Leent EJ, Graeber M, Hedgecock S, Thurston M, Kandra A, Berth-Jones J, Bjerke J, Christophers E, Knop J, Knulst AC, Morren M, Morris A, Reitamo S, Roed-Petersen J, Schoepf E, Thestrup-Pedersen K, Van Der Valk PG, Bos JD: SDZ ASM 981: an emerging safe and effective treatment for atopic dermatitis. Br J Dermatol 2001;144:788-794.

- 82 Ho VC, Gupta A, Kaufmann R, Todd G, Vanaclocha F, Takaoka R, Folster-Holst R, Potter P, Marshall K, Thurston M, Bush C, Cherill R: Safety and efficacy of nonsteroid pimecrolimus cream $1 \%$ in the treatment of atopic dermatitis in infants. J Pediatr 2003; 142:155-162.

83 Kapp A, Papp K, Bingham A, Folster-Holst R, Ortonne JP, Potter PC, Gulliver W, Paul C, Molloy S, Barbier N, Thurston M, de Prost Y: Long-term management of atopic dermatitis in infants with topical pimecrolimus, a nonsteroid anti-inflammatory drug. J Allergy Clin Immunol 2002;110:277-284.

84 Boguniewicz M, Eichenfield LF, Hultsch T: Current management of atopic dermatitis and interruption of the atopic march. J Allergy Clin Immunol 2003;112(6 suppl):S140-S150.
85 Papp KA, Breuer K, Meurer M, Ortonne JP, Potter PC, de Prost Y, Davidson MJ, Barbier N, Goertz HP, Paul C: Long-term treatment of atopic dermatitis with pimecrolimus cream $1 \%$ in infants does not interfere with the development of protective antibodies after vaccination. J Am Acad Dermatol 2005;52:247-253.

86 Stiehm ER, Roberts RL, Kaplan MS, Corren J, Jaracz E, Rico MJ: Pneumococcal seroconversion after vaccination for children with atopic dermatitis treated with tacrolimus ointment. J Am Acad Dermatol, in press.

87 Food and Drug Administration: ODS postmarketing safety review (PID 040609). Pimecrolimus (Elidel, NDA 21-302). 2004: 1-12. http://www.fda.gov/ohrms/dockets/ ac/05/briefing/2005-4089b2_01_04_Pimecrol imus $\% 20$ IMS $\% 20$ Cleared $\% 20$ AE $\% 20$ LT $\% 20$ 2\%20YO $\% 20$ Malignancy.pdf.

88 Food and Drug Administration: ODS postmarketing safety review (PID 040608). Tacrolimus, topical (Protopic, NDA 50-777). 2004: 1-16. http://www.fda.gov/ohrms/dockets/ ac/05/briefing/2005-4089b2_01_03_Tacrolim us $\% 20$ Topical $\% 20$ IMS $\% 20$ Cleared $\% 20$ LT $\% 2$ 02\%20and $\% 20$ Malignancy $\% 20$ Update.pdf.

89 Cunningham-Rundles C, Siegal FP, Cunningham-Rundles S, Lieberman P: Incidence of cancer in 98 patients with common varied immunodeficiency. J Clin Immunol 1987;7:294299.

90 Knowles DM: Immunodeficiency-associated lymphoproliferative disorders. Mod Pathol 1999; 12:200-217.

91 Levine AM: Lymphoma complicating immunodeficiency disorders. Ann Oncol 1994; 5(suppl 2):29-35.

92 Kinlen LJ: Incidence of cancer in rheumatoid arthritis and other disorders after immunosuppressive treatment. Am J Med 1985; 78:4449.

93 Stiehm ER: Conventional therapy of immunodeficiency diseases; in Ochs HD, Smith CIE, Puck JM (eds): Primary Immunodeficiency Diseases: A Molecular and Genetic Approach. New York, Oxford University Press, 1999, pp 448-458.

94 Faye A, Vilmer E: Post-transplant lymphoproliferative disorder in children: incidence, prognosis, and treatment options. Paediatr Drugs 2005; 7:55-65.
95 Swinnen LJ: Post-transplant lymphoproliferative disorders: implications for acquired immunodeficiency syndrome-associated malignancies. J Natl Cancer Inst Monogr 2000; 28:38-43.

-96 Opelz G, Dohler B: Lymphomas after solid organ transplantation: a collaborative transplant study report. Am J Transplant 2004;4: 222-230.

97 Juvonen E, Aalto SM, Tarkkanen J, Volin L, Mattila PS, Knuutila S, Ruutu T, Hedman K: High incidence of PTLD after non-T-cell-depleted allogeneic haematopoietic stem cell transplantation as a consequence of intensive immunosuppressive treatment. Bone Marrow Transplant 2003;32:97-102.

-98 Bonnefoy-Berard N, Vincent C, Verrier B, Revillard JP: Monocyte-independent T-cell activation by polyclonal antithymocyte globulins. Cell Immunol 1992;143:272-283.

99 Curtis RE, Travis LB, Rowlings PA, Socie G, Kingma DW, Banks PM, Jaffe ES, Sale GE, Horowitz MM, Witherspoon RP, Shriner DA, Weisdorf DJ, Kolb HJ, Sullivan KM, Sobocinski KA, Gale RP, Hoover RN, Fraumeni JF Jr, Deeg HJ: Risk of lymphoproliferative disorders after bone marrow transplantation: a multi-institutional study. Blood 1999;94:2208-2216.

100 Draoua HY, Tsao L, Mancini DM, Addonizio LJ, Bhagat G, Alobeid B: T-cell post-transplantation lymphoproliferative disorders after cardiac transplantation: a single institutional experience. Br J Haematol 2004;127: 429-432.

101 Tsai DE, Aqui NA, Vogl DT, Bloom RD, Schuster SJ, Nasta SD, Wasik MA: Successful treatment of T-cell post-transplant lymphoproliferative disorder with the retinoid analog bexarotene. Am J Transplant 2005;5:20702073.

102 Socie G, Henry-Amar M, Bacigalupo A, Hows J, Tichelli A, Ljungman P, McCann SR, Frickhofen N, Van't Veer-Korthof E, Gluckman E: Malignant tumors occurring after treatment of aplastic anemia. European Bone Marrow Transplantation-Severe Aplastic Anaemia Working Party. N Engl J Med 1993;329:1152-1157.

103 Socie G, Rosenfeld S, Frickhofen N, Gluckman E, Tichelli A: Late clonal diseases of treated aplastic anemia. Semin Hematol 2000;37:91-101. 